\title{
DEGRADASI BAHAN ORGANIK LIMBAH CAIR NANAS OLEH BAKTERI INDIGEN
}

\author{
Agus Sutanto \\ Pendidikan Biologi Universitas Muhammadiyah Metro Lampung
}

\begin{abstract}
Pineapple Liquid Waste has high organic material and still unfulfilled required quality standard. Processing occurred at the waste processing installation with pond system (Lagoon) required a wide space and keep long time so that less efficient. Based on this problem, it needs an environmentally sound waste management by utilizing bioprocess technology using indigenous bacteria's ability in degrading organic pollutant called Bioremediation. The objective of this research was to get isolated indigenous bacteria, enables to decrease organic material. It was divided into four stages. First, performed characteristic observation of isolated bacteria that potentially decrease organic material, secondly decomposition capability test in vitro, and thirdly scale bioremediation test pilot plan, fourthly bioremediation test in ex situ at the microbiology laboratory of Malang State University. Data were analyzed by Varian analysis to test the presence or absence of differences and regression test to analyze the link between variables. First phase result: 15 isolated indigenous bacteria.. Potential consortia bacteria consisting of more effective 4 species, indicated by 4 consortia bacteria decreased BOD in 6 days. Starter bacteria with a consortia K1's combination (ABCD), Volume: $5 \%(\mathrm{v} / \mathrm{v})$ and 6 days were the most effective incubation time in decreasing BOD. Second phase result: 1) A significant link among the number of bacteria, a. Bacillus cereus, b. Acinetobacter baumanni, $c$. Bacillus subtilis, d. Pseudomonas pseudomallei and not abcd against organic material with contribution of 72,7\% and negatively correlated, 2) Media treatment and incubation time gave distinctive outcome against organic material, 3) there was a link between organic material organic acid concentration decrease would decrease BOD at scale bioremediation test Pilot plan, and ex situ scale. Threshold BOD achievement limit value on $10^{\text {th }}$ day (75) quality standard: 75 . In accordance with ministry decree LH No. 05 year 2007 industrial wastewater quality standard, suggested to industry to use this study in processing its waste.
\end{abstract}

Keywords: organic material, isolated indigenous bacteria, pineapple liquid waste.

\section{PENDAHULUAN}

Salah satu masalah industri nanas adalah limbah cair nanas memiliki rerata kandungan bahan organik (BOD, Biological Oxygen Demand) tinggi yaitu $338 \mathrm{mg} / \mathrm{l}$ sehingga belum memenuhi Baku Mutu Standart Limbah Industri. Volume limbah setiap hari berkisar 5.000-7.000 $\mathrm{m}^{3}$, sebelum dibuang limbah dikelola dengan cara ditampung dalam kolamkolam IPAL (laguna) selama kurun waktu 2-3 bulan, setelah itu baru dialirkan ke sungai (Julius, 2009). Pengelolaan ini menjadi kurang efisien karena diperlukan waktu lama dan penanganan dengan pembiayaan mahal. Limbah Cair Nanas dengan kandungan keasaman dan bahan organik tinggi melebihi ambang batas baku mutu, dapat mempengaruhi ekosistem perairan.

Eksosistem secara normal akan menyeimbangkan siklus ekologi yang ada, oleh karena itu secara alamiah proses pemulihan limbah oleh bakteri sudah terjadi dengan sendirinya (Atlas, 1993). Limbah Cair Nanas dengan kandungan bahan organik tinggi tidak mampu diuraikan oleh bakteri diperairan atau sungai secara alami, karena volume dan kadar limbah yang tinggi, serta jumlah dan jenis bakteri yang tidak memadai di perairan, untuk itu kualitas LCN harus memenuhi standar baku mutu untuk emisinya.

Salah satu teknologi pengolahan air limbah yang aman dan berwawasan lingkungan adalah menggunakan bakteri yang berpotensi pengurai. Teknologi pengolahan ini biayanya lebih murah daripada menggunakan zat kimia maupun fisika (Droste, 1997). Secara alamiah untuk memperoleh bakteri yang berpotensi sebagai pengurai dapat dilakukan dengan mengisolasi limbah itu sendiri (bakteri indigen), kemudian dikultur secara murni di laboratorium secara in vitro (Labeda, 1990). Pemanfaatan konsorsia bakteri berpotensi yang telah diperbanyak di 
laboratorium dapat digunakan sebagai starter untuk pemulihan air limbah.

$$
\text { Reaksi enzimatis oleh bakteri }
$$

merupakan kunci terselenggaranya proses transformasi bertahap dalam pengelolaan air limbah dari substrat yang umumnya berupa bahan-bahan organik dengan susunan molekul kompleks, menjadi unsur-unsur yang sederhana. Peran mikroba dalam proses pengolahan air limbah sudah banyak memberikan hasil yang menggembirakan. Senyawa-senyawa organik yang terdapat dalam air limbah merupakan sumber nutrisi bagi mikroba. Mikroba akan mengurai senyawasenyawa tersebut menjadi bentuk yang lebih sederhana dan stabil sehingga kadar zat pencemar yang terkandung dalam air limbah tersebut menjadi turun. Bioremediasi merupakan teknik memperbaiki lingkungan melalui suatu proses yang memanfaatkan keberadaan organisme di alam untuk mentransfor- masikan substansi-substansi organik menjadi hasil samping yang tidak toksik (EPA, 2000; Encrata, 2001). Limbah Cair Nanas perlu ditangani melalui alternatif starter alamiah dengan mencari isolat bakteri indigen (bakteri strain lokal) yang memiliki kemampuan menaikkan $\mathrm{pH}$.

\section{METODE. ALAT DAN BAHAN}

Penelitian terbagi menjadi empat tahap, tahap pertama dilakukan observasi karakteristik isolat bakteri yang berpotensi sebagai pengurai limbah organik nanas, Tahap pertama melakukan observasi ke PT Great Giant Pineapple (GGP) Lampung untuk menggali informasi mengenai PT GGP Lampung secara umum dan khusus mengenai IPAL yang dilakukan selama ini, termasuk pemanfaatan bakteri sebagai pengurai limbah. Selanjutnya pengambilan sampel air limbah sebelum masuk IPAL dan seluruh kolam ada. Sampel air limbah kemudian diisolasi dan diidentifikasi di laboratorium mikrobiologi Universitas Negeri Malang dan Fakultas Kedokteran Unibraw Malang, tahap kedua pengujian kemampuan penguraian secara in vitro.

Rancangan penelitian dilakukan dua tahap, pertama menguji konsorsia bakteri (2, 3 dan 4 isolat bakteri) terhadap Limbah Cair Nanas (LCN) steril untuk memperoleh konsorsia paling potensial dilanjutkan tahap kedua, diuji untuk menentukan bentuk konsorsia, volume starter dan waktu inkubasi paling efektif. tahap ketiga dilanjutkan secara pilot plan, tahap pertama diawali pengamatan pertumbuhan bakteri dilakukan secara langsung dengan hemocytometer, Metode Mc Farland dan tidak langsung dengan membiakkan pada media NA. Pengamatan dilakukan setiap 2 jam selama 24 jam meliputi jumlah bakteri dan perubahan $\mathrm{pH}$. Tahap berikutnya dilanjutkan pengamatan degradasi bahan organik Limbah Cair Nanas (LCN) dari parameter $\mathrm{pH}$, dan asam organik selama 6 hari menguji apakah hasil outlet pilot plan pertama dapat digunakan sebagai starter pilot plan kedua tahap keempat pengujian bioremediasi secara ex situ di Laboratorium Mikrobiologi Universitas Negeri Malang Objek penelitian ex situ pertama adalah Limbah Cair Nanas (LCN) tanpa sterilisasi volume 1000 liter, hasil bioremediasi pertama digunakan starter ex situ kedua. Data diuji menggunakan Analisis Varian untuk menguji ada tidaknya perbedaan dan uji regresi untuk menganalisis hubungan antar variabel.

\section{HASIL DAN DISKUSI}

Hasil isolasi bakteri LCN isolat yang memiliki kemampuan menghidrolisis amilum dan protein, adalah Isolat 1,2,3,8,10,11,12,14 dan 15. Isolat menghidrolisis amilium Isolat 4 ,5 dan 7 Isolat 6 dan 13 memiliki kemapuan menghidrolisis protein saja. Perbedaan kemampuan menghidrolisis sangat nyata berbeda diperoleh $\mathrm{P}=0,000(\mathrm{P}<0,01)$ untuk kemampuan menghidrolisis amilum, dan $\mathrm{P}=$ $0,000 \quad(\mathrm{P}<0,01)$ untuk kemampuan menghidrolisis protein. Isolat bakteri potensial untuk degradasi, dipilih berdasarkan kemampuan degradsi organik terpilih isolat bakteri 3,8,10 dan 12. Spesies keempat isolat tersebut bakteri a (Bacillus cereus), Bakteri b (Acinetobacter baumanni), Bakteri c (Bacillus subtilis) dan bakteri d (Pseudomonas pseudomallei).

Variasi waktu (T0, T2, T4 dan T6) serta variasi volume starter (V0,5\%, V1\%, V2,5\% dan $\mathrm{V} 5 \%)$ berbeda sangat nyata $\mathrm{P}=0,000(\mathrm{P}<$ $0,05)$ terhadap kenaikan $\mathrm{pH}$, sedangkan kombinasi konsorsia K1 (ABCD) dan K2 (2A2BCD) tidak berbeda nyata. Volume starter 5\% dan waktu inkubasi 6 hari menunjukkan penurunan BOD paling potensial.

Penelitian skala pilot plan volume 6 liter menunjukkan terdapat perbedaan jumlah bakteri dari variasi waktu inkubasi dan variasi media. Bakteri $\mathrm{b}$ menunjukkan penggandaan tercepat dan waktu 24 jam diperoleh jumlah 
bakteri terbanyak, diikuti bakteri c,d dan a. Pertumbuhan bakteri pada media Limbah Cair Nanas dengan biofilter (media A,B,D dan E) berbeda nyata dibandingkan kontrol dan tanpa biofilter ( $\mathrm{C}$ dan $\mathrm{F})$. Pertumbuhan bakteri $\mathrm{b}$ dengan metode McFarland menunjukkan kecepatan reproduksi dua kali lipat dibandingkan bakteri a,c dan d selama inkubasi 24 jam, bakteri a (Bacillus cereus) $3 \times 10^{8}$ $\mathrm{sel} / \mathrm{ml}$, Bakteri b (Acinetobacter baumanni) $6 \times 10^{8} \mathrm{sel} / \mathrm{ml}$, Bakteri c (Bacillus subtilis) $3 \times 10^{8} \mathrm{sel} / \mathrm{ml}$ dan bakteri d (Pseudomonas pseudmallei) $3 \times 10^{8} \mathrm{sel} / \mathrm{ml}$.

Terdapat hubungan antara jumlah bakteri a. Bacillus cereus, b. Acinetobacter baumanni, c. Bacillus subtilis, d. Pseudomonas pseudomallei dan bukan abcd terhadap $\mathrm{pH}, \mathrm{P}=0,000(\mathrm{P}<0,01)$ untuk semua jenis bakteri atau masing-masing bakteri. dengan kontribusi sebesar $72,7 \%$ dan berkorelasi negatif, berarti kenaikan jumlah bakteri akan diikuti penurunan BOD. Secara parsial bakteri a, b, c, dan d berkorelasi negatif, bakteri b. Acinetobacter baumanni memiliki koefisien determinasi tertinggi yaitu $68,7 \%$. Bakteri selain a,b,c,d korelasi tidak signifikan dan negatif, penurunan bakteri bukan abcd akan menurunkan BOD. Uji linearitas menunjukkan jumlah bakteri terhadap BOD linear $(\mathrm{P}<0,000)$.

Percobaan skala ex situ terdapat perbedaan variasi waktu terhadap parameter BOD, $\mathrm{P}=0,000(\mathrm{P}<0,01)$. Ketercapaian Nilai Ambang Batas BOD pada hari ke 10 sebesar 75 mg/l dibandingkan baku mutu BOD 75 mg/l.

\section{Bakteri Indigen Limbah Cair Nanas (LCN) Dominan pada Instalasi Pengolahan Limbah (IPAL)}

Limbah Cair Nanas yang kaya bahan organik memungkinkan bakteri teradaptasi dengan lingkungan tersebut. Lingkungan yang sangat kaya bahan organik merupakan lingkungan ekstrim bagi mikroorganisme, sehingga mikroorganisme yang berhasil beradaptasi dan tumbuh di lingkungan ini hanya bakteri ekstrimofil (Fogaty, 1983). Bakteri ekstrimofil sudah sejak lama diketahui potensinya dan saat ini banyak dimanfaatkan bioteknologi dalam memproduksi berbagai macam enzim, juga untuk teknologi bioproses.

Pengujian beberapa karakteristik fisiologis menunjukkan bahwa Isolat 3 adalah spesies Bacillus cereus, Isolat 8 adalah spesies
Acinetobacter baumanni, Isolat 10 adalah spesies Bacillus subtilis dan Isolat 12 adalah spesies Pseudomonas pseudomallei. Ciri spesifik B.cereus dan B.subtilis kemampuan menghasilkan enzim hidrolisis senyawasenyawa karbohidrat. Sedangkan A.baumanni memiliki kemampuan hidup pada asam organik yaitu asam sitrat dan asam malat, P. pseudomallei memiliki kemampuan hidup $\mathrm{pH} 2$ - 5,9 dan hidup pada media asam organik (Bergey's, 1994).

Pemilihan keempat spesies bakteri dalam penelitian ini juga diuji untuk mengetahui apakah spesies terpilih tidak patogen. Berdasarkan Uji Hemoglutinase Inhibitation Assay (Barley\&Scotts, 1986) dan termasuk kelompok bahaya II (Deptan, 1988) diperoleh hasil keempat spesies tidak patogen.

\section{Bakteri Indigen Berpotensi mendegradasi Bahan Organik Limbah Cair Nanas}

Spesies-spesies bakteri indigen LCN yang terpilih sebagai inokulan dalam uji biodegradasi adalah: Bacillus cereus, Acinetobacter baumanni, Bacillus subtilis dan Pseudomonas pseudomallei. Kriteria pemilihan keempat spesies ini didasarkan spesies bersifat mendegradasi bahan organik. Bacillus cereus, Acinetobacter baumanni secara memiliki kemampuan degradasi asam organik. Bacillus subtilis dan Pseudomonas pseudomallei secara spesifik memiliki kemampuan degradasi bahan organik selain asam organik, hal ini ditunjukkan kemampuan degradasi BOD yang dominan. Keempat bakteri juga memiliki korelasi posistif terhadap kenaikan $\mathrm{pH}$, Acinetobacter baumanni tertinggi mempengaruhi kenaikan $\mathrm{pH}$. Banyak bakteri menunjukkan kemampuan menguraikan senyawa organik secara aerob namun galur Pseudomonas dan Bacillus merupakan galur yang telah dipelajari secara intensif, baik kemampuan degradasinya (Shen\&Wang, 1995) maupun genetiknya. Pseudomonas adalah bakteri yang penting dalam keseimbangan di alam, secara global aktif dalam dekomposisi secara aerobik dan biodegradasi karena memainkan kunci penting dalam siklus karbon. Pseudomonas termasuk bakteri Gram negatif, sel berbentuk batang yang berukuran 0.5-0.8 x 1-3 $\mu \mathrm{m}$, respirasi secara aerobik, bergerak dengan flagel diujung, beberapa strain ada yang berflagel lateral, bersifat oksidatif, metabolismenya kemoorganotrofik, katalasepositif, oksidase-positif. Spesies Pseudomonas 
di laboratorium mudah tumbuh dengan baik pada media cair yang mengandung bahan organik, pada $\mathrm{pH}$ asam sampai netral, dan pada temperatur mesofilik (Madigan, 2003).

Proses degradasi bahan organik ini secara secara prinsip merupakan proses aerobik dimana senyawa organik dioksidasi menjadi $\mathrm{CO}_{2}, \mathrm{H}_{2} \mathrm{O}, \mathrm{NH}_{4}$ dan biomasa baru. Aktivitas bakteri asam memungkinkan terjadi kenaikan $\mathrm{pH}$ karena $\mathrm{NH}^{+}$akan berikatan dengan air sehingga terbentuk $\mathrm{NH}_{4} \mathrm{OH}$ yang bersifat basa dengan reaksi sebagai berikut.

Enzim bakteri asam

$$
\mathrm{C}_{6} \mathrm{H}_{8} \mathrm{O}_{7} \longrightarrow \mathrm{NH}_{4}^{+}+\mathrm{H}_{2} \mathrm{O}
$$

(asam sitrat)

Enzim-enzim yang bekerja untuk menguraikan karbohidrat, meliputi, enzimenzim pemecah amilum seperti amilase, invertase, laktase, selulase, dan ezim-enzim pemecah pektin seperti poligalakturonase dan pektin metil esterase, sedangkan amilase merupakan enzim pemecah pati atau glikogen.

Irianto (2003) menyatakan amilum adalah senyawa yang memiliki berat molekul tinggi, terdiri atas polimer glukosa yang bercabang-cabang yang diikat dengan ikatan glikosidik. Degradasi amilum membutuhkan enzim amilase yang akan memecah atau menghidrolisis menjadi polisakarida yang lebih pendek (dextrin), dan selanjutnya menjadi maltosa. Hidrolisis akhir maltosa menghasilkan glukosa terlarut yang dapat ditransport masuk ke dalam sel.

Enzim amilase dibedakan menjadi tiga, yaitu a) $\alpha$-amilase, merupakan endoenzim yang bekerja memutus ikatan $\alpha-1,4$ secara acak di bagian tengah molekul amilosa maupun amilopektin. Enzim ini diisolasi dari Bacillus subtilis, b) $\beta$-amilase, suatu eksoenzim yang mengurai unit-unit gula dari ujung molekul amilum, c) Glukoamilase, suatu enzim yang dapat memisahkan glukosa dari terminal gula non-pereduksi substrat amilum (Hidayat, 2008).

Melalui proses mineralisasi protein tersebut akan terbentuk amonium yang merupakan bentuk nitrogen anorganik. Selanjutnya amonium dapat diubah oleh Pseudomonas menjadi bentuk-bentuk nitrit atau nitrat dalam proses nitrifikasi. Nitrat kemudian akan segera direduksi menjadi amonia begitu berada dalam sel bakteri dan bergabung sebagai senyawa organik. Beberapa senyawa organik yang mampu dipecah oleh bakteri
Pseudomonas seperti: selulosa hemiselulosa, pati, protein, asam nukleat kutin, lignin, pektin, inulin dan kitin (Rao, 1994). Penelitian Siahaan dkk (2003) menunjukkan kemampuan Bacillus $s p$ dan Pseudomonas pseudomalei mampu mendegradasi tanah dari cemaran minyak diperkaya bahan organik yang memiliki $\mathrm{pH}$ rendah hingga $95 \%$.

Acinetobacter baumanni merupakan bakteri berbentuk batang, bersifat gram negatif dan aerob. Bakteri ini mampu tumbuh pada berbagai media, dapat memanfaatkan sitrat maupun glukosa sebagai sumber karbon, dan mereduksi nitrat menjadi nitrit. Selama proses fermentasi selain adanya peruraian polimer juga terjadi pembentukan senyawa asam-asam organik sebagai hasil antara yang kemudian akan segera dibentuk menjadi senyawa lain atau gas yang sifatnya tidak asam, misal gas sulfida, fenol, ligno-proteinat, dan sebagainya (Jones et al., 1998).

Judoamijoyo (1990) asam organik dapat digunakan mikrooganisme untuk biosintesis, bila bahan-bahan organik digunakan untuk pertumbuhan bakteri maka $\mathrm{pH}$ cenderung meningkat karena bahan-bahan tersebut akan terdeaminasi. Prescott (2002) deaminasi adalah proses mengkatalisasi pemindahan gugus amino $\left(\mathrm{NH}_{2}\right)$ dari asam amino dan molekul lainnya yang mengandung $-\mathrm{NH}$. Selain itu, proses deaminasi menetralisasikan amin yang menghambat pertumbuhan. Bila mikroba mampu menggunakan sitrat, maka asam akan dihilangkan dari medium biakan, sehingga menyebabkan peningkatan $\mathrm{pH}$.

Austin (1988) menyatakan bahwa Pseudomonas dan Bacillus memilki kemampuan menghasilkan enzim tunggal maupun beberapa enzim untuk degradasi bahan organik. Hasil penelitian memperoleh bakteri yang memiliki kemampuan mendegradasi protein. Protein adalah poli-peptida dengan struktur tertentu, suatu hetero-polimer dari asam amino. Ensim protease (poli-peptidase, oligopeptidase, di-peptidase) merombak protein menjadi peptida yang lebih sederhana atau asam amino. Selanjutnya asam amino mengalami transaminasi, deaminasi, dekarboksilasi, atau dehidrogenasi menjadi zat lain yang lebih sederhana. Secara umum pemecahan bahan organik diperlukan untuk pembentukan energi dan biosintesis, sebab dapat menyediakan karbon untuk berbagai senyawa penting dalam sel. Pada kebanyakan bakteri, asam glutamat adalah asam amino kunci yang dibentuk dari 
sumber amonia dan karbon. Banyak pula bakteri yang dapat mereaksikan amonia dengan asam fumarat membentuk aspartat.

\section{Potensi Konsorsia Bakteri Degradasi Bahan Organik}

Penelitian tahap invitro bertujuan menentukan perlakuan konsorsia inokulum bakteri pengurai yang paling tepat dan waktu yang optimum terhadap penguraian Limbah Cair Nanas (LCN) ditinjau dari parameter BOD dan COD. Penelitian dilakukan dua tahap, pertama menguji konsorsia bakteri dengan 2, 3 dan 4 bakteri terhadap Limbah Cair Nanas (LCN) steril. Setelah diperoleh konsorsia paling potensial dilanjutkan tahap kedua, diuji untuk menentukan bentuk konsorsia, volume starter dan waktu inkubasi paling efektif.

Temuan penelitian pada tahap uji biodegradasi in vitro adalah perlakuan Penggunaan jenis konsorsia secara nyata berbeda dalam reduksi bahan orgnaik Limbah Cair Nanas, penggunaan empat konsorsia paling efektif mereduksi bahan organik LCN ditunjukkan dengan penurunan BOD dan COD. Konsorsia ABCD (A: Bacillus cereus, B: Acinetobacter baumanni, C: Bacillus subtilis dan D: Pseudomonas pseudomallei) diproleh $B O D \quad 75 \mathrm{mg} / \mathrm{l}$ (Nilai Ambang Batas/NAB: $75 \mathrm{mg} / \mathrm{l})$, Konsorsia ABCD dalam mendegradasi LCN memenuhi Nilai Ambang Batas yang dipersyaratkan.

Jumlah bakteri a. Bacillus cereus, b. Acinetobacter baumanni, c. Bacillus subtilis, d. Pseudomonas pseudomallei dan bukan abcd berpengaruh terhadap BOD dengan kontribusi sebesar $72,7 \%$ dan berkorelasi negatif, berarti kenaikan jumlah bakteri akan diikuti penurunan BOD. Secara parsial bakteri a, b, c, dan d berkorelasi positif, bakteri b. Acinetobacter baumanni memiliki koefisien determinasi tertinggi yaitu $68,7 \%$. Bakteri selain a,b,c,d korelasi tidak signifikan dan negatif.

Acinetobacter baumanni bakteri ini mampu tumbuh pada berbagai media, dapat memanfaatkan sitrat maupun glukosa sebagai sumber karbon, dan mereduksi nitrat menjadi nitrit (Jones et al., 1998). Proses fermentasi Limbah Cair Nanas memberikan pengaruh yang cukup berarti bagi perubahan bahan organik, dengan pola mula-mula BOD meningkat kemudian menurun. Fermentasi menggunaan EM-4 dan Bokashi (Jones et al., 1998), perubahannya mempunyai pola yang mirip, yaitu mula-mula BOD meningkat kemudian turun kembali. Ini membuktikan bahwa selama proses fermentasi selain adanya peruraian polimer juga terjadi pembentukan senyawa asam-asam organik sebagai hasil antara yang kemudian akan segera dibentuk menjadi senyawa lain atau gas yang sifatnya tidak asam, misal gas sulfida, fenol, ligno-proteinat, dan sebagainya, sehingga BOD menurun.

\section{KESIMPULAN}

1. Bakteri indigen Limbah Cair Nanas yang mampu menetralkan $\mathrm{pH}$, yaitu: Bacillus cereus, Acinetobacter baumanni, Bacillus subtilis dan Pseudomonas pseudomallei

2. Starter bakteri dengan kombinasi konsorsia $\mathrm{K} 1(\mathrm{ABCD})$, volume 5\% (v/v) dan waktu inkubasi 6 hari paling efektif menurnkan bahan organik (BOD).

3. Ada hubungan antara kadar bahan organik dengan BOD Limbah Cair Nanas, kadar bahan organik mempengaruhi BOD Limbah Cair Nanas sebesar $84,2 \%$. Koefisien korelasi bertanda positif yang berarti bahwa penurunan konsentrasi bahan organik akan menurunkan BOD pada skala pilot plan dan ex situ.

4. Ketercapaian Nilai Ambang Batas $\mathrm{pH}$ pada hari ke $10 \quad(75 \quad \mathrm{mg} / \mathrm{l})$ dan sesuai dengan Kepmen LH No. 05 Tahun 2007 Baku Mutu Air Limbah Industri sebesar $75 \mathrm{mg} / \mathrm{l}$.

\section{UCAPAN TERIMA KASIH}

Peneliti mengucapkan terima kasih kepada Prof. Dr. A.Duran Corebima, M,.Pd., Dr. Ir. Wignyanto, M.S. dan Dr. Endang Suarsini, M.Ked atas bimbingan dan arahannya dalam penelitian ini. Terima kasih kepada PT GGP Lampung khususnya bagian Quality Assursance Departement yang telah membantu pelaksanaan penelitian.

\section{DAFTAR PUSTAKA}

Atlas, R. \& Bartha, R. 1993. Microbial Ecology, Fundamentals and Application. Ed. ke 3. New York: The Benyamin Cummings Publishing Company Inc.

Austin, B. 1988. Methods in Aquatic Bacteriology. John Willey\&Sons.Thomsosn Press (India) Ltd., New Delhi.

Bergey's. Manual of Systematic Bacteriology. Vol. 2. Williams \& Wilkins. Baltimore.

Barley and Scott's . 1986. Diagnostic Microbiology, $7^{\text {th }}$ edition. Mosby. Toronto. 
Deptan (1988) Pedoman Pelaksanaan Pengujian Keamanan Hayati Produk Bioteknologi Seri Jasad Renik. Jakarta. Departemen Pertanian.

Droste, R.L. 1997. Theory and Practice of Water and Wastewater Treatment. USA: John Wiley \& Sons, Inc.

EPA. 2000. Definition of Remediation; Technologies (on line) http://www.epa reachit.org/infohelp/defiehtyp.html.

Diakses 12 April 2009.

Encarta. 2001. World English Dictionsry (North American Edition) (On Line) (http://dictionary.msn.com/find/entry.asp ?refid=186199647. diakses 12 Mei 2009.

Hidayat Nur. Masdiana. Sri Suhartini. 2008. Mikrobiologi Industri. Yogyakarta: Penerbit Andi.

Irianto, Agus. 2003. Petunjuk Praktikum Mikrobiologi. Fakultas Biologi Universitas Jenderal Soedirman. Purwokerto. (on line). http://www.pdfqueen.com/mikrobiologip angan Diakses 12 April 2009.

Jones D.L. and D.D. Brassington. 1998. Scorption of origional bacterial its implication in the rhizosphere. Europ $J$. Soil. Sc.

Judoamidjojo, M., Darwis, A.A. dan Sa'id, E.G., 1990. Teknologi Fermentasi. PAU Bioteknologi. IPB. Jakarta: Rajawali Pers.

Julius S. 2009. (Julius@ggpc.co.id). 21 Pebruari 2009. Kualitas Fisik Kimia IPAL PT Great Green Pineapple Lampung. E-mail kepada Agus Sutanto (sutanto11@gmail.com).

Labeda, D.P. 1990. Environmental Biotechnology.Isolaition of Biotechnological Organisme From Nature.USA: Mc. Graw Hill Publishing Company.

Madigan, M.T., Martinko J.M., Parker J. 2003. Brock Biology of Microorganism Tenth Edition. USA:Prentice-Hall International, Inc.

Prescott, Harley. 2002. Laboratory Exercises in Micrrobiology. The MC-Graw Hill Companies. New York.

Rao, J.F. 1994. Enzymes in the hydrolysis and ol/otbemig of starch. In: Starch: Chemistry and technology. 2" ed. Eds. Whistler, R.L., J.N. Bemiller \& E.F. Paschall. Orlando: Academic Press. Inc.
Sumarsih, Sri. 2003. Diktat Kuliah Mikrobiologi Dasar. Yogyakarta: Jurusan Ilmu Tanah Fakultas Pertanian UPN "Veteran" Yogyakarta.

Shen, H.\&Y.Wang. 1995. Simultancous Chromium Reduction and Phenol Degradation in a Coculture of Escherichia coli ATCC 33456 and Pseudomonas putida DMP-1. Appl. Environ. Microbial 61. 